\title{
ISLAM AND CRIME THE MORAL COMMUNITY OF MUSLIMS
}

\author{
Seyed Hossein Serajzadeh \\ TEACHER TRAINING UNIVERSITY, TEHRAN
}

\begin{abstract}
International crime statistics indicate that in Islamic countries crime rates are lower than in other countries. This feature of Islamic countries is most often explained by two factors: a) the relatively low level of development, which has a positive effect on crime rates, and b) the strictness of Islamic penal law. Providing some evidence, this article maintains that the first factor fails to explain properly the difference in the crime rates of Islamic and non-Islamic countries at a similar level of development. It also argues that the second explanation is a reductionist one. Following a Weberian approach, the article develops the argument that the content and structure of Islamic belief and practice is the dominant shared element among Islamic countries. It has given rise to a particular socio-cultural structure among Muslims, one of the impacts of which has been the low crime rate. Islamic beliefs and practice, therefore, are discussed as the main explanatory factor for the low crime rate in Islamic countries. (Keywords: religion, crime, development, Islam, Shari'a, Islamic law, Muslim attitudes.)
\end{abstract}

"Recite what is sent of the Book by inspiration to thee, and establish Regular Prayer: for Prayer restrains from shameful and evil deeds. And remembrance of God is the greatest (thing in life) and God knows the (deeds) that ye do" (Koran 29:45, trans. A. Yusuf Ali).

\section{Introduction}

Islam is seen by many scholars as a religion that consists of a set of political, economic, legal, and social doctrines that affect every facet of the social life of believers (Kurtz 1995, 106, 135; Groves et al. 1987, 497; Schacht [1964] 1982; Turner 1974, 112; Robertson 1970, 86; Watt, 1961). Koranic teachings promote an ascetic ethic of self-control that bears on virtually all aspects of everyday activity. For Muslims, faith has not merely been a matter of private life and a personal relation with God. It has had pervasive social consequences. Thus, following Stark et al. (1982), it may be argued that Islam develops a strong sense of moral community, where religion is an influential social force generating social sanctions (Groves et al. 1987, 497), and that this contributes to a low crime rate.

Further, within Islam a detailed penal law has been elaborated in 
which severe punishments have been prescribed for many serious criminal acts. Accordingly it has been suggested that the severity of punishments in Islamic penal law accounts for the low crime rate in Islamic countries (Saudi Arabia, Ministry of Interior, 1980; Haroon 1993, 83; Mohammad 1991; Souryal 1990).

The examination of these arguments is the concern of the present writer. Firstly, in order to illustrate the difference between crime rates in Islamic and non-Islamic countries, these will be compared. Secondly, the content of Islamic belief will be discussed, in order to understand its impact on the psychological and cultural formation of Muslim individuals as well as on the development and maintenance of the community of Muslims. Thirdly, we will look at $\operatorname{Shari}^{c} a$ (the Islamic code of behavior) and the content of Islamic penal law (as part of Shari ${ }^{c} a$ ) and then at the effect of this complex on crime. Here a Weberian approach will be followed in two senses. To begin with, like Weber's approach in The Protestant Ethic and the Spirit of Capitalism, the impact of religious (Islamic) creeds on the psychological and cultural formation of individuals and society will be considered, and, moreover, Islamic creeds and $\operatorname{Shari~}^{c} a$ will be treated as an analytical ideal type, the diversity of which will be disregarded (Gerth and Mills 1995, 59-61).

\section{Comparison of Crime Statistics}

In spite of the rise in the general crime rate in recent years, most Islamic countries are still low crime rate societies. In general, Islamic counties are categorised as developing countries, the reported crime rates of which are notably less than those of developed countries (Shelly 1981; United Nations 1993; Fajnzylber et al. 1998, 13). Despite the positive relationship between the level of development and the level of crime, countries with almost the same level of development experience a variety of patterns of criminality and crime rate because of significant historical and cultural differences (Wilson and Herrnstein 1985, 457; Shelly 1981, 50; Bennett 1990, 356).

Looking at crime rates, Shelly $(1981,50-52)$ distinguished three general groups among developing countries: Caribbean countries were characterized by quite a high crime rate, while Middle Eastern and North African (Islamic) countries had a low and stable rate, and Latin American and the rest of the Asian and African countries were between those two extremes. Later reports suggest that almost the same pattern still exists (United Nations 1993; Fajnzylber et al. 1998, 13). ${ }^{1}$

\footnotetext{
${ }^{1}$ There has been great concern among some scholars about the reliability of
} 
Table 1. Average crime rate per 100,000 population of three groups of countries in 1980

\begin{tabular}{|lrrr|}
\hline Type of offence & \multicolumn{2}{c}{ Developing Countries } & Developed \\
Islamic & Non-Islamic & Countries \\
\hline Assault & 36.3 & 132.6 & 183.3 \\
Intentional homicide & 3.2 & 7.0 & 4.5 \\
Non-intentional & & & \\
$\quad$ homicide & 1.4 & 14.1 & 1.9 \\
Drugs & 9.0 & 19.4 & 140.8 \\
Rape & 5.2 & 7.8 & 9.2 \\
Robbery & 2.0 & 75.2 & 49.8 \\
Fraud & 9.4 & 72.8 & 280.1 \\
Theft & 141.2 & 206.5 & 3164.6 \\
Total & 694.2 & 1028.5 & 5968.5 \\
\hline
\end{tabular}

Calculated based on data from Results of the Second United Nations Survey of Crime Trends (United Nations 1992). The countries of each group are as follows:

- Islamic countries: Bangladesh, Kuwait, Pakistan, Qatar, and the United Arab Emirates

- Non-Islamic developing countries: Argentina, Chile, Colombia, Fiji, India, Madagascar, Nepal, Philippines, Republic of Korea, Sri Lanka, Thailand

- Developed Countries: Canada, Denmark, Finland, France, Ireland, Italy, Japan, New Zealand, the Netherlands, Norway, Sweden, the United Kingdom (including Northern Ireland), and the United States

Because of missing data the number of countries based on which the average of each group is computed is less than the number of listed countries.

As can be seen in Table 1, according to United Nations data, while the average total crime rate of Islamic developing countries in 1980 was 694.2 per 100,000 inhabitants, those of non-Islamic developing countries and developed countries were 1028.5 and 5968.5, respectively per

crime statistics for cross-national comparison (Groves et al. 1985, 59-60; Rogers 1989,325$)$. The main reason for this concern is the poor quality of crime statistics from developing countries, in which unreported crimes in particular (the dark figure) are much higher than in statistics from developed countries (Tanner 1983; United Nations 1993, 4). However, an investigation of the reliability of four widely used cross-national data sets on crime has suggested that "for studies seeking aggregate descriptions of world crime or analytic explanations of cross-national crime rates, differences in the data sets do not make a difference in the results" (Bennett and Lynch 1990, 153). Moreover, cross-national comparison of different groups of developing countries may be more reliable because, among them, the quality of crime statistics with respect to the magnitude of dark figures seems to be almost the same. 
100,000 inhabitants. This pattern can be seen in almost all categories of crime, except in non-intentional and intentional homicide and robbery. In these three categories Islamic countries again had the lowest rate, while the rates of non-Islamic developing countries were higher than those of developed countries. Likewise, Fajnzylber et al. have shown that from 1970 to 1994 the intentional homicide rate in Middle Eastern and North African (Islamic) countries was lower than in other groups of countries (1998, 13, fig. 1).

In general, the low crime rate of the Islamic countries can be attributed to several socio-cultural characteristics of these societies. Firstly, Islamic countries have been culturally, to a great extent, homogeneous; in most Islamic countries (particularly Middle Eastern countries) a majority of populations enjoy a remarkable religious and often racial uniformity. Existing ethnic differences are mainly overshadowed by religious harmony, which is a strong basis for national unity. Even in many huge modern cities (mainly the capital cities), religious, racial, and ethnic distinctions, although generally present, are not particularly noticeable.

Secondly, in Islamic countries a cohesive family network has been largely preserved. Even in modern cities, the family network is still impressively effective. It fulfils a considerable role in the process of socialization and provides social support and security for its members (Helal and Coston 1991, 138; Shelly 1981, 50). ${ }^{2}$ Thus, even those who live in big cities do not find themselves alone among the masses, because family and communal relations are active and strong.

Thirdly, in the religious world-view of the peoples of Islamic countries there is more emphasis on the duties of individuals than on their rights. Individuals' interests are regarded as subordinate to social and group interests. Consequently, family, community, and even state interventions in some individuals' private affairs are tolerated and justified for the sake of their social benefits.

Finally, and perhaps as a result of the previous factors, public opinion in Islamic countries is less tolerant of criminal behavior and more favorable towards severe punishments than in other nations (Evans and Scott 1984; Scott and Al-Thakeb 1980, quoted from Wilson and Herrnstein

\footnotetext{
${ }^{2}$ Although divorce is neither prohibited nor especially difficult in Islam, the divorce rate and the singleness rate in Islamic countries have been very low. For instance, in spite of the increase in the number of divorces in recent years in Iran, the proportion of divorces to marriages was 8\% in 1992 (Statistical Centre of Iran 1373/1994-95, 50). Also, a survey study revealed that only 3.3\% of high school students in Tehran had divorced parents (Serajzadeh 1998).
} 
1985, 449-51; Newman 1976). ${ }^{3}$ As far as the comparison of the three selected groups of developing countries is concerned, the strong religious foundation of Islamic countries may be regarded as the core factor underlying the factors we have discussed-homogeneity, a cohesive family net, more emphasis on individual duties than on rights, less tolerance toward criminality - and can account for the low crime rate of these countries. Therefore, as Helal and Coston $(1991,126)$ argue, "the Islamic religion that has formed the underlying current for harmony and norm sharing is largely responsible for the law abiding behavior that results in low crime rates." In order to elaborate this argument it is necessary to look at the particularities of Islam that contribute to low crime rates in Islamic societies.

\section{Islam: Submission to God}

The information contained in this and the following section (4) is largely common knowledge for Muslims and for students of Islam. It bears repeating here, however, because it is a necessary part of the argument made in this study and because certain points of particular relevance to our purpose might otherwise be overlooked. In the following, the contents of Islamic creeds will be briefly introduced and their possible impact on the psycho-social dimensions of Islamic societies that contribute to low crime rates discussed. Muslims are admittedly divided into a variety of denominations and sects. As mentioned above, however, disregarding the diversities, we will consider the core beliefs and rituals in which all Muslims in one sense or another share as an ideal type in a Weberian sense.

The Arabic word islām is commonly taken to mean submission (of oneself to God), and a Muslim is accordingly one who submits to the will of God. God's will, Muslims believe, is revealed in the Koran, which is the word of God dictated to the prophet Mohammed (PBUH). They likewise believe that Mohammed (PBUH) was the last messenger of God and that his teachings reflect the most complete account of the message of the Almighty to human beings. God's word and God's will are thus the central elements of Islamic belief and the main preoccupations of a person brought up in accordance with the dictates of Islamic culture. Islām or "submission" is summed up under the famous five "pillars" in the well-known "hadith of Gabriel," with which Muslim opens his authoritative Sahīh, namely, testifying to the divine unity, ritual prayer, alms, the fast of Ramadan, and the pilgrimage to Mecca (cf.

\footnotetext{
${ }^{3}$ These studies will be discussed in section 5 .
} 
Muslim 1976, 1:3, trans ${ }^{\mathrm{c}}$ Abdul Hamīd Șiddīqī). We will deal with these in section 4 on the rituals of Islam.

\subsection{Articles of Faith}

Alongside islām and its works lies the deeper level of faith ( $\bar{\imath} m \bar{a} n)$ that not all achieve. The articles of faith are generally summarized as being five in number, although there is some difference regarding them and the question of which are "essential." 4 Perhaps the most usual summary is that reflected in the "hadith of Gabriel" just mentioned (Muslim 1976, 1:3-4), which we give in a somewhat expanded form here:

1. belief in one and only one God of the universe (tawhīd);

2. belief in the existence of other spiritual beings, the angels, creatures of God who perform different tasks, including watching over the deeds of humans;

3. belief in prophethood and the revealed scriptures, among which the Koran represents the last and only uncorrupted version of the word of God;

4. belief in the Day of Judgement, when every human being will be held accountable by God;

5. belief in the Divine Decree and Predestination (although God's overwhelming power over the life of people is not generally interpreted so as to remove from them entire responsibility of for their own actions in the framework of their limitations). ${ }^{5}$

Considering the content of the articles of faith, one may readily observe that the most important thing in them is the focus on belief in God, on submission to His will as revealed in the Koran, and on the responsibility of individuals for their behavior before Him on the Day of Judgment. It may be argued that other religions, particularly Christianity and Judaism, share the belief in God, prophethood, revealed scriptures, the

\footnotetext{
${ }^{4}$ Lists of the of the articles of faith vary somewhat from school to school, and not all include faith in the Divine Decree and Predestination among the "essential" beliefs (see., e.g., Koran 2:177, cited in n. 7 below). Cf. Encyclopedia of Islam, new ed., 3:1172a.

${ }^{5}$ It is worth noting that according to Islamic teachings the psychic, social, economic, and political limitations within which one is acting are recognized as elements reducing one's accountability. This leads to lightening of punishment, both in this world and the hereafter. For instance, a Koranic verse stresses that "on no soul doth God place a burden greater than it can bear" (Koran 2:286, trans. A Yusuf Ali). The punishment for burglary, for example, is very harsh according to Islamic law. However, it can be only be carried out if several conditions are met, one of which is that the offender must not be in desperate need of basic requirements of life (see Schacht 1982, 176, 178; Saif 1995a, 1314; Haroon 1993, 28-41; Qutb 1977, 134-35).
} 
Day of Judgment, and an efficacious divine decree. Nonetheless, it seems that Muslims are unique in the extent of their emphasis on submission to God's will in all aspects of life, in the widespread acceptance among them, regardless of sect, of the infallibility of their holy text, and in their stress on the accountability of individuals for all their behavior in this world. ${ }^{6}$ These theological characteristics of Islam, particularly the emphasis on submission to God, have had a visible impact on the sociopsychological, and even political, development of Muslim societies and have made them distinctive from others. This impact is discussed by Robertson (1970, 86-88), who argues that

subscription to the religious point of reference, Allah, in and of itself, is assumed to entail involvement in a religiously bonded social sphere. This emphasis upon the simple act of submission says a lot about the unique feature of Islam. In contrast to Confucianism and Judaism, Islam has definitely been a religion of evangelization - that is, it has sought to widen its social and cultural scope and bring large numbers of individuals within its boundaries.... In contrast to Christianity, Islam through its emphasis on submission, rather than on conversion and induction, reveals again its unique form of dynamism-embracing the social world and sustaining it through the religious impulse.

Giving priority to God's will in all aspects of individual and social life is in open contrast with individualism, at least in its extreme version, which lies at the foundation of Western society. On this matter, Occidental and Islamic cultures are clearly at variance (Turner 1994, 34). That the key notion in Islam of submission to God is articulated through the idea of a personal relationship with Him and the accountability of individuals for all their behavior in this world, moreover, increases the divergence between Islamic and Modern Western culture. Within homogeneous religious communities, an emphasis on personal responsibility for salvation, defined in terms of obedience to God's rules on the one hand and stress on the significance of the community of believers on the other, contributes to a tight social bond and effective control over the individual. The dynamism of this kind of control is highlighted by Marx's observation on Protestantism:

Luther, without question, overcame servitude through devotion but only by substituting servitude through conviction. He shattered the faith in authority by restoring the authority of faith. He transformed the priests into laymen by turning laymen into priests. He liberated man from external religiosity by making religiosity the innermost essence of man. He liberated the body from its chains

\footnotetext{
${ }^{6}$ Whether or not this situation is itself a function of development is a matter of speculation and is not relevant to our purpose here.
} 
because he fettered the heart with chains. (Marx 1972, 18, quoted from Kurtz 1995, 113)

Like Judaism and Catholicism, Islam is regarded as a religion that develops a community-based identity among individuals (Kurtz 1995, 109). Nonetheless, with its emphasis on personal salvation and responsibility, it appears that Islam is in a certain sense more similar to some Protestant sects that effectively internalize their norms and values and strictly control their members (Kurtz 1995, 113). In the process of internalization of religious values and norms, the formulation of religious practice and ritual in Islam seems to play a significant role.

\subsection{The Rituals of Islam}

The religious practices and rituals that accompany the articles of faith are noticeably specific to Islam. These are the well-known "Five Pillars of Islam", summarized in the hadith of Gabriel. In their Islamic form these rituals seem to contribute markedly to the internalization of the articles of faith as well as to the establishment of a sense of a community of believers. They are:

1. the profession of faith (shahāda), which must be uttered with full understanding and which is repeated several times a day during a Muslim's daily prayers; 2. ritual prayer (salāt), which must be performed in a regulated manner five times a day;

3. alms (zakāt), that is, an alms-duty every Muslim should pay, consisting of a proportion of his or her wealth and/or income, either in money or in kind, provided a certain minimum is owned ${ }^{7}$

4. fasting ( $(\mathrm{a} a \mathrm{wm})$ in the month of Ramadan, that is, refraining from eating, drinking, smoking and any sensual pleasures, from sunrise to sunset;

5. making the pilgrimage (hajj) to the holy city of Mecca, which is an obligation on every Muslim physically and financially able to do so, at least once during his or her lifetime - a ritual that functions to invoke the submission of Abraham, the father of the monotheistic religions, to God's will.

\footnotetext{
${ }^{7}$ One of the Koranic verses stipulating zakāt, along with other practices, shows exactly the social and moral dimension of zakät: "It is not righteousness that ye turn your faces towards East or West; but it is righteousness to believe in God and the Last Day, and the Angels, and the Book, and the Messengers; to spend of your substance, out of love for Him, for your kin, for orphans, for the needy, for the wayfarer, for those who ask, and for the ransom of slaves; to be steadfast in prayer, and practice regular charity [zakāt]; to fulfil the contracts which ye have made; and to be firm and patient, in pain (or suffering) and adversity, and throughout all periods of panic. Such are the people of truth, the God-fearing" (2:177, trans. A.Yusuf Ali).
} 
Considering the nature of Muslim belief and practice, one can hardly fail to agree with Aziz $(1995,45)$, when he states that "the basic pillars of belief no doubt play an important role in the psychological and cultural formation of the Muslim individual and serve as a basis for his stands and attitudes towards himself, his community and others." In other words, the essential beliefs and practices of Islam function as a "visible and regular reminder of the believer's duty to uphold God and the ummah at the centre of his or her life" (Kurtz 1995, 110). Not only do they result in the development of a community based identity, they also construct and reinforce a sense of personal accountability. Thus both the beliefs (articles of faith) and practices (pillars) of Islam function to strengthen considerably external and internal sources of control. They must consequently be regarded as significant elements of the social control of crime.

\section{Sharī a or Islamic Law}

On the basis of the foregoing discussion, although an exhaustive comparative study would be necessary to prove our conclusions, we feel it safe to say that the ethos of Islam, viewed alongside that of other religions, is distinguished by its comprehensiveness, that is, it tends to encompass all aspects of the private and social life of Muslims (Kurtz 1995, 106, 135; Groves et al. 1987, 497; Turner 1974, 112; Robertson 1970, 86; also, generally, Schacht 1982 and Watt 1961). Likewise in ethical principles the distinctive feature of Islam, compared with other religions, seems to be its unswerving stress on following rules laid down by God and on strict discipline in private and public life (see Kurtz 1995, 104).

The ethical codes of Islam began to be developed in the early days of the religion by scholar-jurists, ${ }^{8}$ who attempted to discover and elaborate

\footnotetext{
${ }^{8}$ The function of the religious leaders among Muslims, the ${ }^{c} u l a m \bar{a}^{\supset}$ or "learned," is to teach the requirements and the rules of Islam to ordinary people and to attempt to draw up Islamic codes of behavior for new situations (ijtihād). Religious jurisprudence must be based on the Koran, the tradition of the Prophet, reason, and the consensus of previous scholars. What at present is known as Islamic law was mainly developed by scholars relatively early in Islamic history (the eighth to eleventh centuries). By the eleventh century, many scholars considered that ijtihād (religious jurisprudence) had been exhausted by great preceding jurists and that no further development of law was in principle possible (see Turner 1974, 113, and, generally, Schacht 1982). Although Shiite ${ }^{c} u l a m \bar{a}^{\jmath}$ still believe in the possibility of $i j t i h \bar{a} d$, in practice they have been very conservative in changing the content of $\operatorname{Shari}^{c} a$. It must be added that among
} 
Islamic regulations in accordance with the will of God as revealed in the Koran and crystallized in the prophet Mohammed's (PBUH) sayings and deeds (see Schacht 1982, 10-75; also Turner 1974, 113). Shari ${ }^{c} a$, as the sets of religious codes of behavior they produced are called, is usually translated as "Islamic law." This translation, however, may generate misunderstandings, because the coverage of $\operatorname{Shari}^{c} a$ is more comprehensive than that of law. It covers in meticulous detail practically every aspect of human behavior known to the scholar-jurists, from dietary rules to criminal procedures and from the rituals of worship to commercial contracts.

Islamic jurists generally classify all actions into five categories, namely, obligatory (wājib), recommended (mustahabb/mandüb), permissible (mubāh), disapproved (makrūh), and forbidden (harām). This categorization reveals that $\operatorname{Shari}^{c} a$ includes both positive and negative prescriptions, most of which are not legally enforceable, while many aspects of $\operatorname{Shari}^{c} a$ would be generally excluded on the basis of a Western understanding of law (Breiner 1995, 52; Newman 1982, 566-57; De Seife 1994, 4). Broadly speaking, only omitting the first kind of actions (obligatory) and committing the last kind (forbidden) are considered to be sins. The sinner will be subject to punishment either in this world or in the hereafter, or both, if he or she does not repent. Those actions that merit punishment in this world come under the "penal law" of Islam, to which we will return later.

For Muslims, law and religion are completely fused and Muslims' ideological conception of themselves has been that of a "community based on revelation" or a community observing God's law (Watt 1961, 227-81). Moreover, external piety in Muslim society is considered to be a symbol of respecting God's will and of inner belief. Muslims are therefore very sensitive about adhering to the mandates of $\operatorname{Shari}^{c} a$ both in private and in public. For this reason it has been argued that "Shari $\bar{l}^{c} a$ is one of the most important and distinctive features of Islamic civilisation" (Watt 1961,192) and that "Islamic law has had a far greater influence on Muslim society than Western law has had on Western society" (Savory 1976, quoted from De Seife 1994, 4).

Muslims a twofold ethos has developed from the time of early Islam: that of $\operatorname{Shari}^{c} a$ and that of Sufism, which have often challenged and sometimes been in conflict with each other. While Sufism, with its focus on emotion and internal piety, has been impressively influential in Islamic societies, the more rational Shari ${ }^{c} a$, with its focus on external piety, has been the dominant ethos in most Islamic societies. Sufism will therefore not be discussed here. 
Turner (1974, 122-13), dealing with the development of Islamic ethics (that is, $\operatorname{Shari}^{c} a$ ), focuses in particular on the role of the motive of faithful Muslims for clinging to the guidelines of the Koran and the Prophet. He emphasizes, however, the function of $\operatorname{Shari}^{c} a$ for the whole of Muslim society, maintaining that in the unstable situation of the urban life of Islamic societies in the Middle Ages, $\operatorname{Shari}^{c} a$, which "bears all the marks of a law and order campaign," functioned to mitigate social disorder. It "provided a theoretically universal set of norms by which Muslims were held together and, at the same time, the ulema, while identified with the notables, penetrated every level of society" $(1974,104-105)$. However, since (both theoretically and practically) $\operatorname{Shari~}^{c} a$ has remained almost unchanged after its early development, ${ }^{9}$ its application in a changeable social context has, at least in some areas, been met with difficulties. Consequently, though remaining as a sacred and ideal law for Muslims, in practice it has only partially been applied in Muslim society (Schacht 1982, 76-85; Turner 1974, 115-16; Coulson 1978, 1450).

Ironically, as Turner $(1974,116)$ points out, $\operatorname{Sharit}^{c} a$ has remained an ideal ethical system that has, at least potentially, always provided a source of protest against the existing social and political order. It occasionally serves as the ideology of rebellion as defined in Merton's anomie theory (see Merton 1980, 116-22), particularly in the modern world, and provokes social and political unrest. Nonetheless, as a widely accepted social norm, it has for the most part been a source of conformity and social order in Islamic societies. Either way, as Watt (1961, 193) suggests, Sharī $a$ "is recognised at least as an ideal throughout the Islamic world . . . and, even where it is little observed, it sets a standard which has some influence on actual practice." The attitudes of the people towards criminal behavior and criminal procedures are among those aspects of social life in Islamic societies that have patently been stamped by $\operatorname{Shar}^{c} a$ and the corollary penal law of Islam.

\subsection{The Penal Law of Islam}

Since Islamic penal law, which is in some cases very harsh, is part of $\operatorname{Shar}^{c} a$, there have been numerous but few succesful calls for its implementation, and the matter has been the subject of considerable controversy in the Muslim world. The low crime rate of Islamic societies is sometimes attributed to the severity of Islamic penal law and the application of its penalties (Saudi Arabia, Ministry of Interior, 1980; Haroon 1993, 83; Mohammad 1991; Sourial 1990). In order to evaluate this

\footnotetext{
${ }^{9}$ See n. 8.
} 
argument, we must briefly review of the main features of the Islamic penal system.

As previously noted, from the characteristic religious point of view of a Muslim, all actions are subsumed into five categories, ranging from obligatory to forbidden, with three intermediate categories. Committing forbidden actions and omitting obligatory actions are considered sins that will in principle receive their punishment in the hereafter. However, some sins are regarded as crimes that are punishable by the temporal authorities as well. Thus crimes are seen by Muslims as a sub-category of sin, the prevention of which is part of the religious duty of every believer. Because of this, those who commit a crime will be under great informal social pressure from family and members of the community to repent and to compensate for their wrongdoing. However, it is the criminal act, not the criminal himself or herself, that is most rigorously condemned. ${ }^{10}$

Three types of crime are distinguished by Muslim scholar-jurists. The classification is based mainly on the nature of the punishment laid down for the crimes, namely, hadd, qișās, and $t a^{c} z \bar{\imath} r$.

1. Hadd, which literally means limit(ation) or prohibition, refers to punishments laid down in the Koran for unlawful intercourse, false accusation of unlawful intercourse, drinking wine, theft, and highway robbery (cf. Șādiqī 1372/199394, 407-408; Schacht 1982, 178-81). Hadd punishments are considered as the right or claim of God (haqq Allāh). Thus, they are fixed, and after conviction no pardon or amicable settlement is possible. The punishment of these crimes is also very strict, even harsh. In spite of the severity of the proposed penalties, students of the Islamic penal system argue that "there is a strong tendency to restrict the applicability of the hadd punishment as much as possible, except the hadd for false accusation of unlawful intercourse. This in turn serves to restrict the applicability of the hadd for unlawful intercourse itself." (Schacht 1982, 176; see also Saif 1995a, 13-14; Haroon 1993, 28-41.) ${ }^{11}$

${ }^{10}$ In Koran 2:178, which deals with retaliation for murder, the next of kin of the slain person (wali al-dam) is called the "brother" of the murderer and he/she is exhorted to forgive and accept compensation. The translation by A. Yusuf Ali of akhïhi in the verse as "the brother of the slain" does not follow this interpretation. But the text of, for instance, al-Baydāwī's commentary is clear on the matter: ". . akhinhi, that is to say the wali al-dam, named here with the word signifying the brotherhood existing between them [this person and the murderer] in race and in Islam that he might relent and take pity on him." (1846, 1:100). Pickthall's translation gives this meaning: "And for him who is forgiven somewhat by his (injured) brother...."

${ }^{11}$ Some instances of this tendency are as follows: It is strongly recom- 
2. Qișās (retaliation, lex talionis) applies to offences like murder and bodily assault. Since qișa $\bar{s}$ is considered to be the right of the people, the decision to prosecute and punish the offender is the right of the injured party or his or her family. For intentional homicide, they can demand the death penalty, or material compensation, or can completely forgive the offender. Thus, retaliation (the death penalty in the case of murder) depends entirely on the victim or his or her family. Given that people are normally influenced by public opinion, the likelihood of qișass penalties being applied may vary (Haroon 1993, 26-27). Moreover, the Koranic verse on qișās strongly recommends forgiveness and material compensation. ${ }^{12}$

3. The third category of crime is punishable by $t a^{c} z \bar{z} r$. The term legally refers to a penalty that is not fixed because it is not cited in the sacred texts (the Koran or the tradition of the Prophet). In fact, $t a^{c} z \bar{v} r$ is applicable to all crimes that are outside the realm of hadd and qișās crimes. $T a^{c} z \bar{i} r$ is the dynamic part of Islamic penal law, under which Islamic scholar-jurists discussed a variety of offences that could appear at different times and in different societies.

With this overview of Islamic penal law in mind, we can return to the question of the effect of this law on crime in Islamic societies. As previously noted, it is argued that the low crime rate of Islamic societies reflects the severity of punishments in Islamic penal law. However, considering the extreme caution built into Islamic penal law as well as the relative unlikelihood of its being applied in Muslim societies, this argument would seem to be irrelevant. Three reasons may be suggested for the irrelevance of the argument.

Firstly, Islamic penal law has not been the dominant law of the great majority of Islamic countries in recent decades. From the early twentieth century, Islamic countries began to adopt a Western style of criminal, commercial, and general civil law (Coulson 1978, 1452). ${ }^{13}$ The appeal

mended that individuals who witness others' sins do not report the incidents but privately advise the sinner; for unlawful intercourse, four eye-witnesses are required whose statements should be precisely the same, otherwise, they will be convicted for false accusation; the confession of the person who is accused for a hadd crime can be withdrawn, and even the judge should suggest this possibility to the person who has confessed, except in the case of false accusation of unlawful intercourse; For carrying out the punishment for theft, several conditions are required, some of which can rarely be met. One such condition is that the offender should not be a needy person (see Schacht 1982, 176, 178; Saif 1995a, 13-14; Haroon 1993, 28-41; Qutb 1977, 134-35).

12 Koran 2:178. See note 10.

${ }^{13}$ The only exception is Saudi Arabia, where a traditional approach to Islamic law has long been in force. Most recently, under the influence of the 
for the application of Islamic law in Muslim countries, as a general demand of the Islamic revival movement, has appeared mainly in recent years. ${ }^{14}$ In a few countries, like Iran, the movement has been able to reintroduce $\operatorname{Shari}^{c} a$ law as the basis of the penal system. At present, however, in only a few Islamic counties is the penal law of Islam put more or less into effect. In general, therefore, the low crime rate of Islamic countries cannot be attributed to the application of the Islamic penal law and the severity of its punishments.

Secondly, there are three dimensions of punishment that may affect crime: severity, certainty, and celerity (Davis and Stasz 1990, 44). With respect to these dimensions, Islamic penal law would appear to introduce a high level of punishment. Nonetheless, with respect to the likelihood of conviction and the execution of punishment, it enjoys a low level of certainty. As previously noted, Islamic penal law tends to restrict the application of hadd punishment. The application of qișās punishment, moreover, depends entirely on the decision of the victim or of his or her family, who are exhorted to forgive the offender. Regarding celerity, Islamic penal law, in its traditional form, seems to be very swift. Nevertheless, as far as its application in modern times in a few Islamic countries is concerned - we may take the example of Iran - the judicial system has adopted a modern model of organization and procedure. As a consequence, owing to the nature of bureaucratic process, the penal system in Iran is about as quick, or slow, as in other countries.

The third and last reason to doubt that the stringency of Islamic penal law accounts for the low crime rate of Islamic societies is connected with the general controversy over the relationship between the level of punishment and the crime. The prohibiting impact of the level of punishment has been a matter of dispute among criminologists. While empirical studies seem to suggest a positive relationship between the certainty of punishment and the crime rate, most studies fail to prove the existence of a relationship between the severity of punishment and the crime rate

Islamic revival movement, the application of $\operatorname{Shari}^{c} a$ law has emerged as a strong social demand. However, not all Muslim revivalists believe in application of the traditional version of $\operatorname{Shari}^{c} a$. Therefore, what is applied in Iran as Islamic Law is to a great extent different from what has been applied in Saudi Arabia, or what was applied recently in Afghanistan by the Taliban, who adopted to a considerable extent tribal rules as those of $\operatorname{Shari}^{c} a$.

${ }^{14}$ It must be noted that among Muslims there are various interpretations of the content of $\operatorname{Shari}^{c} a$ and the ways in which it may apply (see the last parts of section 6). 
(Tittle 1969; Davis and Stasz, 1990, 44; Mohammad 1991, 83-89, 9196). Given the disputes on this matter on the one hand, and the fact that Islamic penal law enjoys severity but not certainty on the other, it is reasonable to question whether the severity of punishment in Islamic penal law has any significant effect on the crime rate.

We think that Islamic penal law, in a particular sense, has indeed been an effective element contributing to the low crime rate in Islamic societies; namely, that as part of $\operatorname{Shari}^{c} a$ Islamic penal law has been considered by Muslims as an "Ideal" to be respected (Watt 1961, 193; Schacht 1982, 199; Saif 1995b, 121). In other words, for Muslims, Shari ${ }^{c} a$ reflects God's will, prohibiting wrongdoing and indicaing the way to salvation. Thus, the more severe the suggested penalty for an action, the more sinful the action is according to Muslims. In this regard, comparing the crime rate of Saudi Arabia with those of surrounding Muslim countries, Souryal $(1990,295)$ concludes that the application of Shari ${ }^{c} a$ undoubtedly plays a role in keeping the crime rate of Saudi Arabia low. However, he adds that "unlike Western style positive laws, Shari ca reflects an expanded view of socio-religious rules based on the principles of prevention, conditioning, bonding, moralizing, and punishment."

In general, therefore, it may be concluded that if Islamic penal lawas part of $\operatorname{Shari}^{c} a$-has had a real prohibitive effect on crime, it is not simply because it is applied as formal penal law. It is mainly because the complex of religious ideas to which it belongs has had a great influence on the mentality of Muslims. Watt's suggestion cited above (p. 121) that even when $\operatorname{Shari}^{c} a$ is little observed it sets a standard that is to some extent influential in the actual practice of Muslims thus seems to be warranted. Consequently, regardless of whether the official penal law is based on $\operatorname{Shari}^{c} a$ or not, public opinion in Muslim countries can be expected to be stricter towards crime, particularly towards those offences named in the penal law of Islam that are considered to have an especially devastating effect on the moral health of the society. In summary, Islamic penal law has had its prohibitive effect on crime as a normative system respected by Muslims, and not just as a penal law that threatens offenders.

\section{Muslim Attitudes towards Crime: Empirical Evidence}

The argument that, as a normative system, $\operatorname{Shari}^{c} a$ and the penal law of Islam have had an impact on Muslims' negative attitudes towards crime may be supported by the findings of a few empirical studies. In these studies the attitudes of Muslims towards the seriousness of particular kinds of deviant behaviour were compared with those of other nations. In a cross-national study conducted by Newman (1976), people in six coun- 
tries (India, Indonesia, Iran, Italy, Yugoslavia, and the USA) were asked about nine activities that are generally recognized as deviant behaviour in most cultures: robbery, incest, appropriation of public funds, homosexuality, abortion, taking drugs, factory pollution, public protest, and not helping a person in danger. Among several other questions, the respondents were asked, "Do you think this act should be prohibited by law?" The average of positive answers across the set of acts for the countries was as follows: Indonesia, 89.6; Iran, 87.6; Italy, 84.7; Yugoslavia, 77.0; India, 72.7; and the USA, 58.1 (Newman 1976, 116). Considering this as a rough indicator of the social tolerance of crime (cf. Wilson and Herrnstein 1985, 448), the results suggest that public opinion regarding criminal acts in Islamic countries (Indonesia and Iran) is stricter than in non-Islamic countries.

In another cross-national study, Scott and Al-Thakeb (1980, quoted from Wilson and Herrnstein 1985, 450-51 and fig.) ranked the perceived seriousness of several categories of crime. The study included eight samples from Denmark, Finland, Holland, Britain, Kuwait, Norway, Sweden, and the USA. The subjects were asked to assign suitable penalties for some twenty offences. Kuwait is remarkably different from the other countries in two respects: the severity of suggested penalties and the rank of crimes with respect to the severity of recommended punishments. Kuwaitis proposed heavier punishments than the nationals of other countries for all categories of offenses. The penalties they suggested for violent, drug-related, and sexual offences were far more severe, while those they suggested for economic crimes and propertyrelated offenses were somewhat harsher.

Moreover, based on two samples of American and Kuwaiti students, Evans and Scott (1984) measured the seriousness of a list of offences. Their findings were consistent with the previous findings. As can be seen in table 2, Kuwaitis were tougher regarding all categories of offences.

Table 2. Mean Seriousness of Offence Category: United States and Kuwait

\begin{tabular}{|lrr|}
\hline & United States & Kuwait \\
Offence Category & Mean Seriousness & Mean Seriousness \\
\hline Violent & 11.2 & 11.6 \\
Property & 7.8 & 8.4 \\
White Collar & 6.1 & 7.8 \\
Morals & 4.1 & 10.5 \\
\hline
\end{tabular}

Source: Evans and Scott 1984, 52.

The observed differences with respect to the social tolerance of crime between Islamic and non-Islamic countries may conceivably be ex- 
plained by the level of development (Grove et al. 1987). The fact that almost all non-Islamic countries included in the previously discussed studies were developed countries may give support to the argument that emphasizes the significance of the level of development. However, based on the data given in these studies, it is difficult to distinguish between the effects of Islamic culture and those of modernity. In order to examine precisely the effect of Islamic culture on the significantly different crime rates of Islamic developing countries and non-Islamic developing countries shown above in Table 1 (p. 113), one must compare public opinion towards crime in these countries.

Of course the process of development and modernity, as it has happened so far, has weakened traditional family, community, and religious bonds. Consequently, it has changed traditional attitudes towards crime in favor of greater tolerance of at least some categories of crime. In this regard, Islamic countries seem to be no exception. Nevertheless, it can be argued that, because of the great role played by religion, the process of development itself in Islamic societies is strongly influenced by Islamic teachings. Thus it is very likely that public opinion in Islamic countries will remain more sensitive towards crime, particularly towards offences against public decency and personal morality (modesty in male-female relations, sexual morality, and drug and alcohol codes), even when the effect of the development variable is controlled.

In this light, it does not seem unlikely that the fact that Islamic countries are categorized as a low crime rate group among developing countries (Shelly 1981, 50-52; cf. section 2) should be attributed to their Islamic cultural legacy. The argument that Islam plays a role in the difference in the crime rates of developing countries may be supported, moreover, by Newman's (1976) earlier cited study, in which the average judgment of illegality in samples from two Islamic countries, Indonesia and Iran, was stricter than that of an Indian sample (see the first paragraph of this section).

\section{Conclusion}

In sum, belief, ritual, and practice have placed God, His word, and His will at the center of Muslim life. The development in Islam of the set of religious and moral precepts collectively known as $\operatorname{Shari~}^{c} a$ that cover almost all aspects of life is a result of this fact. The penal system of Islam, as part of this moral system, has some influence on the individual and social consciousness of Muslims, even when it is not in practice enforced. This influence may act as a constraint that inhibits crime and consequently contributes to the low crime rate of Islamic societies. 
The application of $\operatorname{Shari}^{c} a$ has been a matter of serious controversy in Islamic societies. This debate, however, lies far beyond the concerns of the present study. Nonetheless, it should be noted that in spite of the strength and popularity of the Islamic revitalization trend, which emphasizes bringing Islamic values to bear in regulating society, the movement is a heterogeneous one, within which two main interpretations of Islamization and $\operatorname{Shari~}^{c} a$ can be distinguished. Traditional Islamists are loyal to the reading of $\operatorname{Shari}^{c} a$ that was developed by early Muslim scholarjurists, and they consider that reading to be on the level of divine law and unchangeable. Modernist Islamists, in contrast, criticize the thesis of the continued validity of the body of doctrine developed by medieval scholars to respond to the necessities of their age (cf. Schacht 1982; Coulson 1978, 1454-55; Saif 1995a, 9-19; Saif 1995b, 120-23). While traditionalists have pursued a nostalgic quest for past communal values, modernists have attempted to create an Islamic version of modernity by reflecting on and embracing the values of the modern world as well as the general principles of Islam (cf. Turner 1994, 92-95).

During recent decades the socio-economic structure of Islamic societies has been modernizing and has changed dramatically. Religion, however, has remained an influential force in the social life of Muslims. They still show great concern for obeying God's will and observing Koranic teachings in their everyday life. It seems that the voices of modern Islamists have had louder echoes than those of traditionalists. Nonetheless, the modernist approaches to Islamic revitalization tend to present not only a more moderate but also a more individualistic interpretation of Islamic law. One may therefore ask whether or not modernist versions of Shari ${ }^{c} a$, or Islam in general, can create the social consensus that the more stringent traditionalist versions have succeeded in creating so far.

Muslim societies have shown that they have been able to preserve their religious commitment in the modern world to a great extent (Turner 1994, 92-95). However, they have not yet experienced fully, or reflected seriously on, the late modernity and globalisation era, in which an allembracing religious ethos seems very difficult to practice (Kurtz 1995, 106; Robertson 1970, 88). Nonetheless, whatever the form and the strength of religion in the era of late modernity will be (cf. Beckford 1996, 30-47; Berger 1997), it could be argued that religion is more fervently practiced and more effectively maintained in Muslim societies than in others. This is undoubtedly a result of the dynamism of the motivation of being submissive to God among Muslims. This dynamism, as previously discussed, generated in the traditional world a particular version of sacred law that has made Islam different from other religions 
with respect to the application of religious codes in the everyday life of believers, and it has maintained Islam as a strong vigorous religion in the modern world. Thus, if the future of any culture is stamped by its heritage (which it is), then it is more likely that the dynamism of submission to God will lead Muslims to create new versions of $\operatorname{Sharī}^{c} a$ that preserve their classical religious sentiments and codes more effectively than others will be able to do with their traditional religious and ethical systems. Hence, if religious sentiments, in a general sense, function to control criminality, then it may be argued that when the level of development (modernity) and other variables affecting crime are controlled, perhaps Islamic societies will continue to experience lower crime rates than their counterparts.

\section{REFERENCES}

Aziz, Mokhtar Ihsan. 1995. "Notes on Shari'ah, Fiqh and Ijtihad." In Religion, Law and Society, ed. Tarek Mitri. Geneva: WCC Publications.

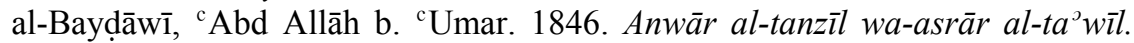
Ed. H. O. Fleischer. Leipzig: Vogel.

Beckford, James A. 1996. "Postmodernity, High Modernity, and New Modernity: Three Concepts in Search of Religion." In Postmodernity, Sociology, and Religion, ed. K. Flanagan and P. C. Jupp. London: Macmillan.

Bennett Richard R., and James P. Lynch. 1990. "Does a Difference Make a Difference? Comparing Cross-National Crime Indicators," Criminology 28 (1): $153-82$.

Berger, Peter. 1997. "Against the Current." Prospect (March 1997): 32-36.

Breiner, Bert F. 1995. "Shari'a and Religious Pluralism In Religion, Law and Society, ed. Tarek Mitri. Geneva: WCC Publications.

Coulson, Noel J. 1978. "Law and Religion in Contemporary Islam." The Hastings Law Journal 29:1447-57.

Davis, Nanette J., and, Clarice Stasz. 1990. Social Control of Deviance: A Critical Perspective. New York: McGraw-Hill.

De Seife, Rodolphe J. A. 1994. The Shar'ia: An Introduction to the Law of Islam. San Francisco: Austin \& Winfield.

Evans Sandara S., and Joseph E. Scott. 1984. "The Seriousness of Crime CrossCulturally." Criminology 22 (1): 39-59.

Encyclopaedia of Islam. New edition. Leiden: E. J. Brill, 1960-2002.

Fajnzylber, Pablo, Daniel Lederman, and Norman Loayza. 1998. Determinants of Crime Rates in Latin America and the World: An Empirical Assessment. Washington: The World Bank.

Gerth, H. H., and C. Wright Mills, eds. and trans. 1995. From Max Weber: Essays in Sociology, London: Routledge. 
Groves, W. Byron et al. 1985. "Religion, Modernisation, and World Crime." Comparative Social Research 8:59-78.

. 1987. "Islam, Modernization and Crime: A Test of the Religious Ecology Thesis." Journal of Criminal Justice 15:495-503.

Haroon, Muhammad. 1993. Islam and Punishment. Lahore: Vision Islamic Publications, in affiliation with Raza Academy, Stockport, UK.

Helal, Adel A., and Charisse T. M. Coston. 1991. "Low Crime Rates in Bahrain: Islamic Social Control, Testing the Theory of Synnomie." International Journal of Comparative and Applied Criminal Justice 15 (1): 125-44.

Koran. Trans. A. Yusuf Ali. Brentwood, Maryland: Amana Corp., 1883.

. Trans. Mohammed Marmaduke Pickthall (various editions).

Kurtz, Lester R. 1995. Gods in the Global Village: The World's Religions in Sociological Perspective. Thousand Oaks, California: Pine Forge Press.

Marx, Karl. 1972. The Marx Engels Reader, ed. Robert C. Tucker. New York: Norton.

Merton, Robert K. 1980. "Social Structure and Anomie." In Theories of Deviance, eds. Stuart H. Traub and Craig B. Little. New York: F. E. Peacock.

Mohammad, Ni'ma Karrar. 1991. "The influence of the application of Shariy'a on crime and public security: The Sudan case." Ph.D. diss., University of Durham.

Muslim b. al-Hajjāj al-Qushayrī. 1976. Șaḥịh Muslim. Trans. ' Abdul Hamīd Șiddīqī. Lahore: Sh. Muhammad Ashraf.

Newman, Graeme R. 1976. Comparative Deviance: Perception and Law in Six Cultures. New York: Elsevier Scientific Pub. Co.

1982. "Khomeini and Criminal Justice: Notes on Crime and Culture." The Journal of Criminal Law and Criminology 73 (2): 561-81.

Qutb, Muhammad. 1977. Islam, the Misunderstood Religion. Damascus: Holy Koran Publishing House.

Robertson, Ronald. 1970. The Sociological Interpretation of Religion. Oxford: Basil Blackwell.

Rogers, John D. 1989. "Theories of Crime and Development: A Historical Perspective." Journal of Development Studies 25:314-28.

Șādiqī, Muhammad Hādī. 1372/1993-94. "Girāyish-i kayfarī-yi huqūq-i jazā-yi islām.” Doctoral diss., Dānishgāh-i Tarbiyat-i Mudarris, Tehran.

Saif, Walid. 1995a. "Shari'ah and Modernity." In Religion, Law and Society, ed. Tarek Mitri. Geneva: WCC Publications.

. 1995b. "Human Rights and Islamic Revivalism." In Religion, Law and Society, ed. Tarek Mitri. Geneva: WCC Publications.

Saudi Arabia, Ministry of Interior. 1980. The Effect of Islamic Legislation on Crime Prevention in Saudi Arabia: Proceedings of the Symposium Held in Riyadh, 16-21 Shawal, 1396 A.H. (9-13 October, 1976). [Riyadh]: Ministry of Interior, Kingdom of Saudi Arabia, Crime Prevention Research Centre.

Savory, R. M., ed. 1976. Introduction to Islamic Civilisation. Cambridge: Cambridge University Press. 
Schacht, Joseph. [1964] 1982. An Introduction to Islamic Law. Oxford: Oxford University Press.

Scott, J. E., and F. Al-Thakeb. 1980. "Perception of Deviance CrossCulturally." In Crime and Deviance: A Comparative Perspective, ed. G. R. Newman. Beverly Hills, California: Sage Publications.

Serajzadeh, Seyed Hossein. 1998. "Muslims, religiosity and delinquency: An examination of Iranian youth." Ph.D. diss., University of Essex.

Shelley, Louise I. 1981. Crime and Modernization: The Impact of Idustrialization and Urbanization on Crime. Carbondale, Illinois: Southern Illinois University Press.

Souryal, Sam S. 1990. "Religious Training as a Method of Social Control." In Essays on Crime and Development, ed. Uglješa Zvekić. Rome: United Nations Interregional Crime and Justice Research Institute.

Stark, Rodney et al. 1982. "Religion and Delinquency: The Ecology of a 'Lost' Relationship." Journal of Research in Crime and Delinquency 19:4-24.

Statistical Centre of Iran. 1373/1994-95. Sālnāma-i āmārī-i sāl-i 1372 (Iran statistical yearbook 1372/1993-94). Tehran: Statistical Centre of Iran.

Tanner, R. E. S. 1983. Law and Order Statistics in the Third World. Brighton: IDS Publications.

Tittle, Charles R. 1969. "Crime Rates and Legal Sanctions.” Social Problems 16:409-423.

Turner, Bryan S. 1974. Weber and Islam: A Critical Study. London: Routledge \& Kegan Paul. ledge.

United Nations. 1992. Trends in Crime and Criminal Justice, 1970-1985, in the Context of Socio-Economic Change: Results of the Second United Nations Survey of Crime Trends, Operations of Criminal Justice Systems and Crime Prevention Strategies. New York: United Nations.

. 1993. Crime Trends and Criminal Justice Operations at the Regional and Interregional Levels: Results of the Third United Nations Survey of Crime Trends, Operations of Criminal Justice Systems and Crime Prevention Strategies. New York: United Nations.

Watt, W. Montgomery. 1961. Islam and the Integration of Society. London: Routledge \& Kegan Paul.

Weber, Max. 1976. The Protestant Ethic and the Spirit of Capitalism. Trans. Talcott Parsons. London: Allen \& Unwin.

Wilson, James Q., and Richard J. Herrnstein. 1985. Crime and Human Nature. New York: Simon and Schuster. 